\title{
Quality Characteristics and Sensory Properties of Reduced-fat Emulsion Sausages with Brown Rice Fiber
}

\author{
Yun-Sang Choi ${ }^{1}$, Hyun-Wook Kim², Dong-Heon Song ${ }^{2}$, Ji-Hun Choi ${ }^{3}$ Jinhee Park ${ }^{3}$, \\ Mun-Yong $\mathrm{Kim}^{3}$, Chun-Son $\mathrm{Lim}^{3}$, and Cheon-Jei Kim ${ }^{1,2 *}$ \\ ${ }^{1}$ Research Institute for Meat Science and Culture, Konkuk University, Seoul 143-701, Korea \\ ${ }^{2}$ Department of Food Science and Biotechnology of Animal Resources, Konkuk University, Seoul 143-701, Korea \\ ${ }^{3}$ Food Ingredients Solution Center, CJ Cheiljedang Corporation, Seoul 152-051, Korea
}

\begin{abstract}
We evaluated the effects of dietary fiber extracted from brown rice on the quality of reduced-fat emulsion sausage. Reduced-fat emulsion sausage was supplemented with brown rice fiber at levels of $0,1,2,3$, and $6 \%$. Adding different levels of brown rice fiber affected the proximate composition of the reduced-fat emulsion sausages $(p<0.05)$, except for protein content. Adding different levels of brown rice fiber influenced the physicochemical properties of the reduced-fat emulsion sausages. The cooking yield, emulsion stability, textural properties, and viscosity of the reduced-fat emulsion sausages containing brown rice fiber improved with increases in added brown rice fiber $(p<0.05)$. The reduced-fat emulsion sausages containing 1-3\% brown rice fiber generated sensory evaluation scores similar to those of the high-fat sausage control. These results indicate that reduced-fat emulsion sausages with 1-3\% added brown rice fiber had the most acceptable sensory properties and highest quality characteristics compared to the others.
\end{abstract}

Key words: reduced-fat, dietary fiber, brown rice fiber, textural properties, sensory properties

\section{Introduction}

Emulsion sausage is one of the most popular traditional meat products in the world, and traditional emulsion sausage contains up to $30 \%$ fat (Choi et al., 2010a). Fat plays major roles in meat emulsion sausage processing by stabilizing the meat emulsion, reducing cooking loss, and improving water holding capacity and binding properties (Choi et al., 2009). In particular, fat provides flavor, juiciness, and a desirable mouth feel (Choi et al., 2010b). However, high fat intake is related to obesity, hypertension, cardiovascular disease, and coronary heart disease, because of the high amounts of saturated fatty acids and cholesterol (Jiménez-Colmenero, 1996). Many studies have shown that high animal fat intake is correlated with an independent risk for high blood pressure and this is the main reason for reducing the animal fat content in meat products (Choi et al., 2007, 2009). As a result, the popu-

\footnotetext{
*Corresponding author: Cheon-Jei Kim, Department of Food Science and Biotechnology of Animal Resources, Konkuk University, Seoul 143-701, Korea. Tel: 82-2-450-3684; Fax: 82-2-444-6695, E-mail: kimcj@konkuk.ac.kr
}

larity of emulsion sausage with high levels of animal fat has decreased. Furthermore, consumers who value their health have been demanding reduced-fat and healthier meat products (Chin et al., 2008; Choi et al., 2008). The increasing demand for reduced-fat diets has led the meat product industry to develop or modify traditional food products to contain less animal fat (Choi et al., 2009).

Reduced-fat meat products and replacing animal fat with non-meat ingredients such as dietary fiber, isolated soy protein, carrageenan, and konjac flour should result in healthier products (Cofrades et al., 2000; FernándezGinés et al., 2004; Hughes et al., 1997; 1998). According to Mansour and Khalil (1997), wheat is an excellent replacement for fat in meat products as compared to regular meat products. Adding wheat fiber reduces cholesterol content by $4-65 \%$ and caloric value by $13-42 \%$. Dietary fiber plays a major role in the human diet, not only for its nutritional properties but also for its functional and technological properties (Choi et al., 2009; 2010b; 2011). Dietary fiber can be added to emulsion meat products to reduce cooking loss due to its water and fat binding properties and to enhance texture (Cofrades et al., 2000). Many researchers have evaluated various natu- 
ral sources of dietary fiber such as rice bran, rye bran, wheat bran, oat bran, lemon albedo, hazelnut pellicle, seaweed, citrus peel, mango, and carrot, but a limited number of studies have reported on dietary fiber from brown rice added to reduced-fat emulsion meat products (Choi et al., 2009; Cofrades et al., 2000; FernándezGinés et al., 2004; Fernández-López et al., 2008; Huang et al., 2005; Yilmaz, 2005; Yilmaz and Dağlioğlu, 2003).

The objective of this study was to evaluate replacing animal fat with water and brown rice fiber by studying proximate composition, $\mathrm{pH}$, color, cooking yield, emulsion stability, textural profile, viscosity, and sensory characteristics of reduced-fat emulsion sausage.

\section{Materials and Methods}

\section{Preparation of dietary fiber from brown rice}

Brown rice fiber was prepared from rice bran using the method of Park et al. (2009). Fresh rice bran containing $12-16 \%$ moisture was obtained from a polishing plant in China. The rice bran was pelletized into a $2-10 \mathrm{~mm}$ size using a pellet-forming machine. The rice bran pellets were dried until the moisture content was $<10 \%$. Hexane (2-5 fold by weight) was added and circulative lipidextraction was conducted until the residual oil content in the rice bran was $3 \%$. De-fatted rice bran was obtained by removing the residual hexane at a temperature $<60^{\circ} \mathrm{C}$. To the de-fatted rice bran, 8-40 fold of water by weight was added, and the mixture was stirred with shaking for 30-60 min to uniformly disperse the particles in the mixture. Subsequently, $3 \mathrm{~N} \mathrm{NaOH}$ was slowly added to the mixture at $20-30^{\circ} \mathrm{C}$ to adjust the $\mathrm{pH}$ to $8-10$, and protein was extracted for 30-60 min. The resulting protein solution was centrifuged at more than $5,000 \mathrm{~g}$ and ambient temperature. The precipitate was dried, crushed, sieved, roasted, cooled, pulverized, and sieved to prepare the brown rice fiber. The roasting and pulverization processes were performed to increase the microbiological safety and sensory preference during the food application.

\section{Preparation of reduced-fat emulsion sausage}

Fresh pork (M. biceps femoris, M. semitendinosus, $M$. semimembranosus, moisture, $71.97 \%$; fat, $4.96 \%$; protein, $15.82 \%$ ) and pork back fat (moisture, $12.61 \%$; fat, $85.64 \%$ ) were purchased from a local processor at $48 \mathrm{~h}$ postmortem. All subcutaneous and intramuscular fat and visible connective tissue were removed from the fresh ham muscle. Lean material and pork back fat were ground through an 8-mm plate. The ground tissues were vacuum packaged (FJ-500XL, Fujee Tech, Korea) and stored at $0^{\circ} \mathrm{C}$ until required for product manufacture. Suitable amounts of muscle and fat were tempered at $4^{\circ} \mathrm{C}$ for $24 \mathrm{~h}$ prior to meat batter preparation. Six different emulsion sausages were produced (Table 1). The first emulsion sausage was the control prepared with $30 \%$ pork back fat. The other five emulsion sausages were prepared with reduced-fat and added brown rice fiber. Each batch of samples consisted of five emulsion sausages differing in composition with respect to the brown rice fiber level added $(0,1,2,3$, and $6 \%$ ). Pork meat was homogenized and emulsified for $1 \mathrm{~min}$ in a silent cutter (Cutter Nr-963009, Hermann Scharfen GmbH \& Co, Postfach, Germany). Nitrite pickled salt $(1.5 \%), 0.3 \%$ sodium tripolyphosphate, $0.02 \%$ ascorbic acid, 0.06\% mono-sodium L-glutamate, and $0.6 \%$ bratwurst spice were added to the meat, which had been previously dissolved in water and chilled $\left(2^{\circ} \mathrm{C}\right)$ and

Table 1. Reduced-fat emulsion sausage formulations with added brown rice fiber

\begin{tabular}{|c|c|c|c|c|c|c|}
\hline \multirow{2}{*}{ Ingredient } & \multirow{2}{*}{ Control } & \multicolumn{5}{|c|}{ (Treatments ${ }^{1)}$} \\
\hline & & $\mathrm{T} 1$ & $\mathrm{~T} 2$ & $\mathrm{~T} 3$ & $\mathrm{~T} 4$ & T5 \\
\hline Pork meat & 50 & 50 & 50 & 50 & 50 & 50 \\
\hline Back fat & 30 & 20 & 20 & 20 & 20 & 20 \\
\hline Ice & 20 & 30 & 29 & 28 & 27 & 24 \\
\hline Brown rice fiber & 0 & 0 & 1 & 2 & 3 & 6 \\
\hline Total & 100 & 100 & 100 & 100 & 100 & 100 \\
\hline Nitrite pickled salt & 1.5 & 1.5 & 1.5 & 1.5 & 1.5 & 1.5 \\
\hline Sodium phosphate & 0.5 & 0.5 & 0.5 & 0.5 & 0.5 & 0.5 \\
\hline Ascorbic acid & 0.02 & 0.02 & 0.02 & 0.02 & 0.02 & 0.02 \\
\hline Mono sodium glutamate & 0.06 & 0.06 & 0.06 & 0.06 & 0.06 & 0.06 \\
\hline Bratwurst & 0.6 & 0.6 & 0.6 & 0.6 & 0.6 & 0.6 \\
\hline
\end{tabular}

${ }^{1)}$ Control, high-fat emulsion sausage without brown rice fiber; T1, reduced-fat emulsion sausage without brown rice fiber; T2, reducedfat emulsion sausage with $1 \%$ brown rice fiber; T3, reduced-fat emulsion sausage with $2 \%$ brown rice fiber; T4, reduced-fat emulsion sausage with $3 \%$ brown rice fiber; $\mathrm{T} 5$, reduced-fat emulsion sausage with $6 \%$ brown rice fiber 
then mixed for $1 \mathrm{~min}$. Brown rice fiber was added to the samples and the batters were emulsified for $6 \mathrm{~min}$. A temperature probe (Kane-May, KM330, UK) was used to monitor the emulsion temperature, which was maintained at $<10^{\circ} \mathrm{C}$ throughout batter preparation. After emulsification, the meat batter was stuffed into collagen casings (\#240, NIPPI Inc., Japan; approximate diameter of 25 $\mathrm{mm}$ ) using a stuffer (Stuffer IS-8, Sirman, Marsango, Italy). The meat samples were then heated to $75 \pm 2^{\circ} \mathrm{C}$ for $30 \mathrm{~min}$ in a water bath (Model 10-101, Dae Han Co., Korea). The cooked meat batter was cooled with cold water $\left(15^{\circ} \mathrm{C}\right)$. The emulsion sausage was then placed in polyethylene bags, vacuum packaged using a vacuum packaging system, and maintained at $<10^{\circ} \mathrm{C}$ during preparation. This procedure was performed in triplicate for each emulsion sausage (each using $10 \mathrm{~kg}$ frankfurters). All analyses were conducted in triplicate for each formulation.

\section{Proximate composition}

Compositional properties of the samples were obtained using AOAC methods (2000). Moisture content (950.46B, oven air-drying method) was determined by weight loss after $12 \mathrm{~h}$ of drying at $105^{\circ} \mathrm{C}$ in a drying oven (SW-90D, Sang Woo Scientific Co., Korea). Fat content (960.69, ether extractable component) was determined by the Soxhlet method with a solvent extraction system (Soxtec $^{\circledR}$ Avanti 2050 Auto System, Foss Tecator AB, Sweden), and protein content (981.10) was determined by the Kjeldahl method with an automatic Kjeldahl nitrogen analyzer (Kjeltec ${ }^{\circledR}$ 2300Analyzer Unit, Foss Tecator AB). Ash content was determined according to AOAC method 923.153 (muffle furnace).

\section{Cooking yield}

The emulsion sausages were weighed before heat processing and after chilling at $2^{\circ} \mathrm{C}$ for $24 \mathrm{~h}$. The cooking yield was determined from their weights and expressed as a percentage of the initial weight.

Cooking yield (\%)

$=($ Emulsion sausage weight after cooking $(\mathrm{g})$

/ Emulsion sausage meat batter weight before cooking (g) $) \times 100$

\section{Emulsion stability}

The emulsion meat batters were analyzed for emulsion stability using the method of Bloukas and Honikel (1992) with the following modifications. At the middle of a 15 mesh sieve, pre-weighed graduated glass tubes (Pyrex Chojalab Co., Korea, volume: $15 \mathrm{~mL}$, graduated units: $0.2 \mathrm{~mL}$ ) were filled with batter. The glass tubes were closed and heated for $30 \mathrm{~min}$ in a boiling water bath to a core temperature of $75 \pm 1^{\circ} \mathrm{C}$. After cooling to $4 \pm 1^{\circ} \mathrm{C}$, to facilitate fat and water layer separation, the total expressible fluid and fat separated in the bottom of each graduated glass tube were measured and calculated (Choi et al., 2007).

Total expressible fluid separation $(\mathrm{mL} / \mathrm{g})$

$=(($ the water layer $(\mathrm{mL})+$ the fat layer $(\mathrm{mL}))$

/weight of raw meat batter $(\mathrm{g})) \times 100$

Fat separation $(\mathrm{mL} / \mathrm{g})$

$=(($ the fat layer $(\mathrm{mL}) /$ weight of raw meat batter $(\mathrm{g})) \times 100$

\section{pH}

The $\mathrm{pH}$ values of the samples were measured in a homogenate prepared with $5 \mathrm{~g}$ of sample and distilled water $(20 \mathrm{~mL})$ using a $\mathrm{pH}$ meter (Model 340, MettlerToledo $\mathrm{GmbH}$, Switzerland). All determinations were performed in triplicate.

\section{Color evaluation}

The color of each emulsion meat batter preparation and sausage was determined using a colorimeter (Minolta Chroma meter CR-210, Japan; illuminate C, calibrated with a white plate, $\mathrm{CIE} \mathrm{L}^{*}=+97.83$, CIE $\mathrm{a}^{*}=-0.43$, CIE $\mathrm{b}^{*}=$ $+1.98)$. Six measurements for each of five replicates were taken. Lightness (CIE L* - value), redness (CIE a ${ }^{*}$ - value), and yellowness (CIE b ${ }^{*}$ - value) values were recorded.

\section{Texture profile analysis (TPA)}

TPA was performed at room temperature with a texture analyzer (TA-XT2i, Stable Micro Systems, Godalming, UK). Emulsion sausage samples were taken from the central portion of each meat batter preparation. Prior to analysis, samples were equilibrated to the room temperature $\left(20^{\circ} \mathrm{C}, 3 \mathrm{~h}\right)$. The texture analysis conditions were as follows: pre-test speed, $2.0 \mathrm{~mm} / \mathrm{s}$; post-test speed, $5.0 \mathrm{~mm} / \mathrm{s}$; maximum load, $2 \mathrm{~kg}$; head speed, $2.0 \mathrm{~mm} / \mathrm{s}$; distance, 8.0 $\mathrm{mm}$; force, $5 \mathrm{~g}$. The TPA values were obtained by graphing a curve using force and time plots. Values for hardness (kg), springiness, cohesiveness, gumminess (kg), and chewiness $(\mathrm{kg})$ were determined as described previously (Bourne, 1978).

\section{Apparent viscosity}

Emulsion meat batter viscosity was measured in tripli- 
cate with a rotational viscometer (HAKKE Viscotester ${ }^{\circledR}$ 500, Thermo Electron Corp., Germany) set at $10 \mathrm{rpm}$. The standard cylnder sensor (SV-2) was positioned in a 25 $\mathrm{mL}$ metal cup filled with batter and allowed to rotate under a constant share rate at $\mathrm{s}^{-1}$ for $60 \mathrm{~s}$ before each reading was taken. Apparent viscosity values in centipoises were obtained. The temperature of each sample at the time $\left(18 \pm 1^{\circ} \mathrm{C}\right)$ of viscosity testing was also recorded (Shand, 2000).

\section{Sensory evaluation}

Reduced-fat emulsion sausages samples were evaluated for color, flavor, juiciness, tenderness, and overall acceptability. The samples were served to 12 experienced panel members. Each sample was coded with a randomly selected three-digit number. All sensory evaluations were performed under fluorescent lighting. Panelists were instructed to cleanse their palates between samples using water. The color $(1=$ extremely undesirable, $10=$ extremely desirable $)$, flavor $(1=$ extremely undesirable, $10=$ extremely desirable $)$, tenderness $(1=$ extremely tough, $10=$ extremely tender), juiciness $(1=$ extremely dry, $10=$ extremely juicy), and overall acceptability ( 1 = extremely undesirable, $10=$ extremely desirable) of the cooked samples were evaluated using a 10-point hedonic scale.

\section{Statistical analysis}

An analysis of variance was performed on all the variables measured using the general linear model (GLM) procedure of the SAS statistical package (SAS Institute, 2008). Duncan's multiple range tests $(p<0.05)$ was used to determine differences between treatment means.

\section{Results and Discussion}

\section{Proximate composition}

The proximate compositions of the reduced-fat emul- sion sausage formulated with various levels of brown rice fiber are shown in Table 2. The moisture content of the samples with reduced-fat and brown rice fiber was higher than that in the controls, because the reduced-fat treatment samples had 20\% more water and brown rice fiber added (Table 1). These results agree with those reported by Choi et al. (2010b), who found significantly increased moisture content in reduced-fat meat emulsion systems with added dietary fiber, as the addition of rice bran fiber increased the water holding capacity of the meat batters. Additionally, Fernández-Ginés et al. (2004) indicated that lemon albedo as a source of dietary fiber increased the moisture content of bologna sausage. Similar trends in moisture content were observed by García et al. (2002) for the moisture content of dry fermented sausage supplemented with wheat, oat, and fruit fiber, which were higher than that of the control due to the high water retention of the fiber. Protein content was not significantly different among the all samples $(p>0.05)$. The fat content was significantly lower in the reduced-fat emulsion sausages formulated with brown rice fiber compared to that in the controls $(p<0.05)$. Similar results were observed by Luruena-Martinez et al. (2004) who obtained similar quality characteristics for low-fat frankfurters with added locust bean and xanthan gum. Choi et al. (2010a) found significant differences in fat content when vegetable oil replaced pork back fat in reduced-fat frankfurters. For this reason, the fat levels of the reduced-fat emulsion sausages were close to the target value, because the treatment sample has less fat added. The ash content was higher in samples containing brown rice fiber than that in the control, as brown rice fiber has higher ash content $(p<0.05)$. Similar results were obtained by Fernández-Ginés et al. (2004) who studied the characteristics of low-fat sausage with added lemon albedo. Lee et al. (2008) indicated that the ash content of sausage supplemented with kimchi was higher than that in the control without kimchi fiber.

Table 2. Proximate composition of reduced-fat emulsion sausage with various levels of added brown rice fiber

\begin{tabular}{lcccccc}
\hline \multirow{2}{*}{ Traits } & \multirow{2}{*}{ Control } & \multicolumn{5}{c}{ Treatments $^{1)}$} \\
\cline { 3 - 7 } & & T1 & T2 & T3 & T4 & T5 \\
\hline Moisture (\%) & $49.57 \pm 1.12^{\mathrm{D}}$ & $53.23 \pm 0.98^{\mathrm{C}}$ & $56.89 \pm 0.65^{\mathrm{B}}$ & $57.28 \pm 0.45^{\mathrm{B}}$ & $58.30 \pm 0.83^{\mathrm{AB}}$ & $59.40 \pm 0.77^{\mathrm{A}}$ \\
Protein (\%) & $14.62 \pm 0.85$ & $14.96 \pm 1.02$ & $14.96 \pm 0.94$ & $14.95 \pm 0.75$ & $14.96 \pm 0.82$ & $14.94 \pm 0.68$ \\
Fat (\%) & $31.89 \pm 0.73^{\mathrm{A}}$ & $25.52 \pm 0.76^{\mathrm{B}}$ & $24.45 \pm 0.82^{\mathrm{BC}}$ & $24.47 \pm 0.63^{\mathrm{BC}}$ & $23.50 \pm 0.54^{\mathrm{C}}$ & $23.48 \pm 0.81^{\mathrm{C}}$ \\
Ash (\%) & $1.48 \pm 0.12^{\mathrm{D}}$ & $1.51 \pm 0.18^{\mathrm{D}}$ & $2.12 \pm 0.13^{\mathrm{D}}$ & $2.83 \pm 0.08^{\mathrm{C}}$ & $3.22 \pm 0.14^{\mathrm{B}}$ & $4.08 \pm 0.10^{\mathrm{A}}$ \\
\hline
\end{tabular}

All values are mean $\pm \mathrm{SD}$ of three replicates.

${ }^{\text {A-D }}$ Means within a row with different letters are significantly different $(p<0.05)$.

${ }^{1)}$ Control, high-fat emulsion sausage without brown rice fiber; T1, reduced-fat emulsion sausage without brown rice fiber; T2, reducedfat emulsion sausage with $1 \%$ brown rice fiber; T3, reduced-fat emulsion sausage with $2 \%$ brown rice fiber; T4, reduced-fat emulsion sausage with $3 \%$ brown rice fiber; $\mathrm{T} 5$, reduced-fat emulsion sausage with $6 \%$ brown rice fiber 
Turhan et al. (2005) reported that low-fat beef burgers with hazelnut pellicle had increased ash content compared to that in a control. In general, researchers have observed that ash content increases significantly when adding dietary fiber to meat products.

\section{Cooking yield and emulsion stability}

The cooking yields of the emulsion sausage prepared with various levels of added brown rice fiber are shown in Fig. 1. The reduced-fat emulsion sausages without brown rice fiber treatment $(\mathrm{T} 1)$ had the lowest cooking yield $(p<0.05)$, and the cooking yields of reduced-fat emulsion sausage increased significantly as the level of added brown rice fiber increased $(p<0.05)$. Many researchers have found that dietary fiber can be added to meat products such as sausage, patties, jerky, and nuggets to increase cooking yield due to its water and fat binding properties (Choi et al., 2010a; Fernández-Ginés et al., 2004; Piñero et al., 2008). Similar results were obtained by Lee et al. (2008) in which breakfast sausages with added kimchi fiber had increased cooking yield. Anderson and Berry (2000) showed that lower-fat beef patties with added inner pea fiber had increased cooking yields. Choi et al. (2009) reported that dietary fiber from different sources has been studied alone or combined with other ingredients in meat products to increase cooking yields and improve water and fat binding capacities. Dietary fiber from

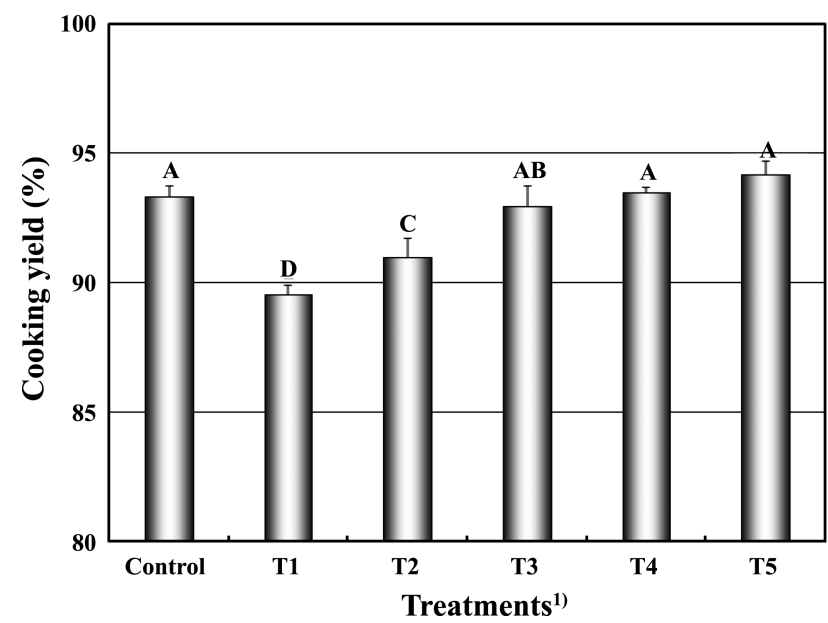

Fig. 1. Cooking yield of reduced-fat emulsion meat batters containing various levels of added brown rice fiber. A-D Means with different letters are significantly different $(p<0.05) .{ }^{1)}$ Control, high-fat emulsion sausage without brown rice fiber; $\mathrm{T} 1$, reduced-fat emulsion sausage without brown rice fiber; $\mathrm{T} 2$, reduced-fat emulsion sausage with $1 \%$ brown rice fiber; $\mathrm{T} 3$, reduced-fat emulsion sausage with $2 \%$ brown rice fiber; $\mathrm{T} 4$, reduced-fat emulsion sausage with $3 \%$ brown rice fiber; $\mathrm{T} 5$, reduced-fat emulsion sausage with $6 \%$ brown rice fiber brown rice is useful due to its ability to enhance cooking yield in meat products.

The emulsion stability of emulsion sausage is an index that estimates the physical properties of a meat product and is an indicator of unseparated water and fat retained by meat proteins (Choi et al., 2010b; Saricoban et al., 2008). Adding brown rice fiber to meat emulsion batters had significant effects on emulsion stability (Fig. 2). Total expressible fluid separation was the highest in the reduced-fat without brown rice fiber treatment (T1) but the total expressible fluid separation of reduced-fat emulsion batters decreased significantly as the level of brown rice fiber added increased $(p<0.05)$. Fat separation of emulsion batter prepared without brown rice fiber (control and T1) was significantly higher than that in treatments with brown rice fiber $(p<0.05)$. This effect was observed by Choi et al. (2009) as the proportion of rice bran fiber increased, the total expressible fluid separation of a meat emulsion system decreased. Choi et al. (2010b) observed a decrease in emulsion stability in a chicken emulsion system, which agreed with the present. According to Wong and Cheung (2000), the major contribution to water binding in meat products is added dietary fiber from seaweeds, which leads to improved emulsion stabil-

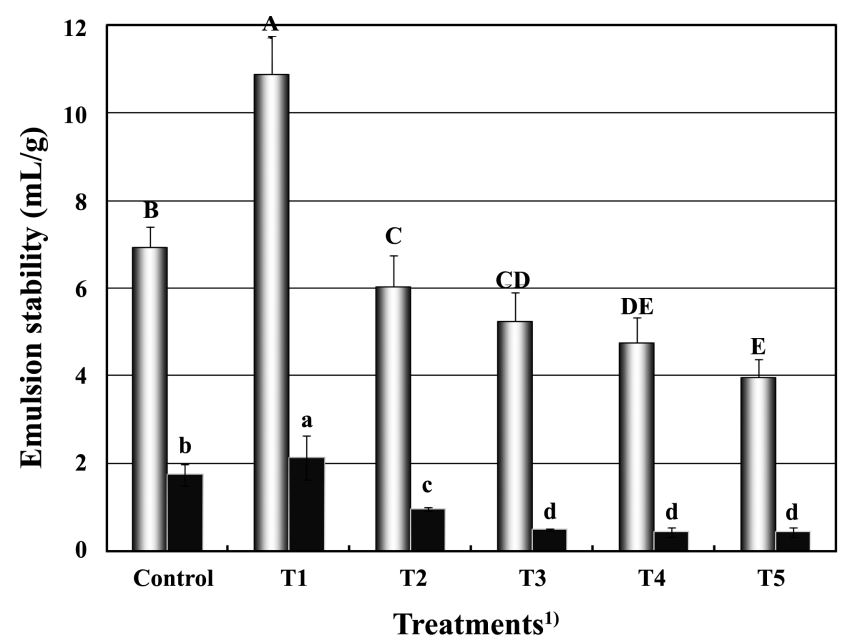

Fig. 2. Emulsion stability of reduced-fat emulsion meat batters containing various levels of added brown rice fiber ( $\square$ : total expressible fluid separation (\%), $\square$ : fat separation (\%)). ${ }^{\mathrm{A}-\mathrm{E}}$ Means with different letters are significantly different $(p<0.05)$. ${ }^{\mathrm{a}-\mathrm{d}}$ Means with different letters are significantly different $(p<0.05) .{ }^{1)}$ Control, highfat emulsion sausage without brown rice fiber; T1, reduced-fat emulsion sausage without brown rice fiber; $\mathrm{T} 2$, reduced-fat emulsion sausage with $1 \%$ brown rice fiber; T3, reduced-fat emulsion sausage with $2 \%$ brown rice fiber; T4, reduced-fat emulsion sausage with $3 \%$ brown rice fiber; $\mathrm{T} 5$, reduced-fat emulsion sausage with $6 \%$ brown rice fiber 
ity. Cofrades et al. (2008) reported that several factors that can affect emulsion stability of meat batter with added dietary fiber. In general, dietary fiber from natural sources improves the physical properties of emulsion meat products by influencing the matrix structure of the meat emulsion systems, because meat products provide the greatest emulsion stability.

\section{pH and color}

The $\mathrm{pH}$ values in the reduced-fat meat batters and sausages with various concentrations of added brown rice fiber are shown Table 3. The $\mathrm{pH}$ of the reduced-fat meat batters and emulsion sausages increased significantly as the brown rice fiber concentration increased $(p<0.05)$. Choi et al. (2011) reported that the $\mathrm{pH}$ of meat products is higher with increased levels of added rice bran fiber, because the rice bran fiber contains high levels of minerals such as iron, phosphorus, and calcium. Similar results were reported for the influence of rice bran fiber on the $\mathrm{pH}$ of meat batters and frankfurters (Choi et al., 2007, 2009, 2010b). Also, the $\mathrm{pH}$ was higher in the reduced-fat emulsion sausages than that in the raw emulsion meat batters. For this reason, the $\mathrm{pH}$ of meat products increase when cooked due to the imidazolium that is unfolded and exposed, which acts as a basic activity due to the histidine (Choi et al., 2008, 2009).

The differences in lightness, redness, and yellowness values of reduced-fat meat batters and emulsion sausages were significantly affected by the concentration of added brown rice fiber (Table 3). The highest lightness values of the meat batters and emulsion sausages were obtained in the control. The lightness values decreased significantly with increasing levels of added brown rice fiber $(p<0.05)$. The redness and yellowness values of meat batters and emulsion sausages increased significantly with increasing added brown rice fiber concentration $(p<0.05)$. These results agree with those of Choi et al. (2010a) who indicated that the color of the meat product changes when rice bran fiber is added to a formulation. Sánchez-Zapata et al. (2010) indicated that color evaluations of pork burgers with added tiger nut fiber show increased lightness and yellowness values, and decreased redness values. Normally, all of the instrumental color evaluations for meat and meat products are affected by the color of the added dietary fiber extracted from natural sources (Eim $e t$ al., 2008; Lee et al., 2008; Saricoban et al., 2008).

\section{TPA and viscosity}

The textural properties of the reduced-fat emulsion sausages are presented in Table 4. The reduced-fat emulsion sausage treatments with increasing added brown rice fiber had higher hardness, cohesiveness, gumminess, and chewiness $(p<0.05)$, but springiness was not affected. These results suggest that changes in added brown rice fiber levels significantly affected the textural characteristics of the reduced-fat emulsion sausage $(p<0.05)$. Similar increases in hardness, gumminess, and chewiness were found for frankfurters and meat products due added kimchi fiber, rice bran fiber, wheat fiber, and other types of dietary fiber (Choi et al., 2007; 2010a; Cofrades et al., 2000; Lee et al., 2008). This result agrees with that of Vural et al. (2004) who studied the effects of vegetable oil and sugar beet fiber on the textural properties of reduced-fat frankfurters. Some researchers have indicated that meat prod-

Table 3. pH values and instrumental color of reduced-fat meat batters and sausages containing various levels of added brown rice fiber

\begin{tabular}{|c|c|c|c|c|c|c|c|}
\hline \multirow{2}{*}{\multicolumn{2}{|c|}{ Traits }} & \multirow{2}{*}{ Control } & \multicolumn{5}{|c|}{ Treatments $^{1)}$} \\
\hline & & & $\mathrm{T} 1$ & $\mathrm{~T} 2$ & $\mathrm{~T} 3$ & $\mathrm{~T} 4$ & $\mathrm{~T} 5$ \\
\hline \multirow{4}{*}{$\begin{array}{l}\text { Meat } \\
\text { batter }\end{array}$} & $\mathrm{pH}$ & $6.48 \pm 0.03^{\mathrm{C}}$ & $6.44 \pm 0.08^{\mathrm{C}}$ & $6.46 \pm 0.04^{\mathrm{C}}$ & $6.54 \pm 0.03^{\mathrm{B}}$ & $6.61 \pm 0.04^{\mathrm{A}}$ & $6.60 \pm 0.07^{\mathrm{A}}$ \\
\hline & CIE L* & $75.72 \pm 4.25^{\mathrm{A}}$ & $71.78 \pm 3.66^{\mathrm{B}}$ & $70.89 \pm 2.92^{\mathrm{BC}}$ & $70.03 \pm 1.44^{\mathrm{BC}}$ & $68.60 \pm 1.68^{\mathrm{C}}$ & $64.77 \pm 2.10^{\mathrm{D}}$ \\
\hline & $\mathrm{CIE} \mathrm{a}^{*}$ & $3.88 \pm 0.20^{\mathrm{B}}$ & $3.83 \pm 0.54^{\mathrm{B}}$ & $3.77 \pm 0.42^{\mathrm{B}}$ & $4.57 \pm 0.82^{\mathrm{A}}$ & $5.02 \pm 0.81^{\mathrm{A}}$ & $5.08 \pm 0.58^{\mathrm{A}}$ \\
\hline & $\mathrm{CIE} \mathrm{b}^{*}$ & $13.21 \pm 0.81^{\mathrm{E}}$ & $13.07 \pm 1.80^{\mathrm{E}}$ & $17.22 \pm 1.50^{\mathrm{D}}$ & $20.20 \pm 1.61^{\mathrm{C}}$ & $22.42 \pm 1.56^{\mathrm{B}}$ & $24.14 \pm 1.10^{\mathrm{A}}$ \\
\hline \multirow{4}{*}{$\begin{array}{c}\text { Emulsion } \\
\text { Sausage }\end{array}$} & $\mathrm{pH}$ & $6.50 \pm 0.06^{\mathrm{BC}}$ & $6.48 \pm 0.06^{\mathrm{C}}$ & $6.50 \pm 0.03^{\mathrm{BC}}$ & $6.56 \pm 0.01^{\mathrm{B}}$ & $6.63 \pm 0.04^{\mathrm{A}}$ & $6.66 \pm 0.05^{\mathrm{A}}$ \\
\hline & CIE L ${ }^{*}$ & $76.57 \pm 0.87^{\mathrm{A}}$ & $73.28 \pm 1.22^{\mathrm{B}}$ & $71.65 \pm 1.15^{\mathrm{C}}$ & $69.62 \pm 1.08^{\mathrm{D}}$ & $68.81 \pm 1.02^{\mathrm{D}}$ & $66.58 \pm 1.99^{\mathrm{E}}$ \\
\hline & CIE a* & $5.84 \pm 0.77^{\mathrm{A}}$ & $4.92 \pm 0.62^{\mathrm{B}}$ & $5.15 \pm 0.67^{\mathrm{B}}$ & $5.99 \pm 0.52^{\mathrm{A}}$ & $6.03 \pm 0.48^{\mathrm{A}}$ & $5.90 \pm 0.56^{\mathrm{A}}$ \\
\hline & $\mathrm{CIE} \mathrm{b}^{*}$ & $10.48 \pm 0.88^{\mathrm{E}}$ & $9.91 \pm 0.65^{\mathrm{E}}$ & $12.21 \pm 0.72^{\mathrm{D}}$ & $13.59 \pm 0.74^{\mathrm{C}}$ & $15.00 \pm 0.53^{\mathrm{B}}$ & $18.47 \pm 0.55^{\mathrm{A}}$ \\
\hline
\end{tabular}

All values are mean $\pm \mathrm{SD}$ of three replicates.

${ }^{\mathrm{A}-\mathrm{E}}$ Means within a row with different letters are significantly different $(p<0.05)$.

${ }^{1)}$ Control, high-fat emulsion sausage without brown rice fiber; T1, reduced-fat emulsion sausage without brown rice fiber; T2, reducedfat emulsion sausage with $1 \%$ brown rice fiber; T3, reduced-fat emulsion sausage with $2 \%$ brown rice fiber; T4, reduced-fat emulsion sausage with $3 \%$ brown rice fiber; $\mathrm{T} 5$, reduced-fat emulsion sausage with $6 \%$ brown rice fiber 
Table 4. Texture profile analysis of reduced-fat sausages containing various levels of added brown rice fiber

\begin{tabular}{lllllll}
\hline \hline \multirow{2}{*}{ Traits } & \multirow{2}{*}{ Control } & \multicolumn{5}{c}{ Treatments $^{1)}$} \\
\cline { 3 - 7 } & & \multicolumn{1}{c}{$\mathrm{T} 1$} & \multicolumn{1}{c}{$\mathrm{T} 2$} & $\mathrm{~T} 3$ & $\mathrm{~T} 4$ & $\mathrm{~T}$ \\
\hline Hardness (kg) & $0.29 \pm 0.03^{\mathrm{BC}}$ & $0.23 \pm 0.02^{\mathrm{D}}$ & $0.26 \pm 0.03^{\mathrm{C}}$ & $0.28 \pm 0.03^{\mathrm{BC}}$ & $0.30 \pm 0.03^{\mathrm{B}}$ & $0.40 \pm 0.06^{\mathrm{A}}$ \\
Springiness & $0.96 \pm 0.02$ & $0.96 \pm 0.02$ & $0.96 \pm 0.05$ & $0.95 \pm 0.04$ & $0.96 \pm 0.02$ & $0.94 \pm 0.02$ \\
Cohesiveness & $0.48 \pm 0.03^{\mathrm{AB}}$ & $0.52 \pm 0.06^{\mathrm{A}}$ & $0.45 \pm 0.04^{\mathrm{B}}$ & $0.47 \pm 0.03^{\mathrm{AB}}$ & $0.50 \pm 0.04^{\mathrm{A}}$ & $0.52 \pm 0.11^{\mathrm{A}}$ \\
Gumminess (kg) & $0.15 \pm 0.02^{\mathrm{B}}$ & $0.12 \pm 0.03^{\mathrm{C}}$ & $0.12 \pm 0.02^{\mathrm{C}}$ & $0.13 \pm 0.03^{\mathrm{C}}$ & $0.15 \pm 0.03^{\mathrm{B}}$ & $0.22 \pm 0.03^{\mathrm{A}}$ \\
Chewiness (kg) & $0.15 \pm 0.02^{\mathrm{B}}$ & $0.12 \pm 0.02^{\mathrm{C}}$ & $0.12 \pm 0.03^{\mathrm{C}}$ & $0.13 \pm 0.02^{\mathrm{C}}$ & $0.16 \pm 0.04^{\mathrm{B}}$ & $0.21 \pm 0.05^{\mathrm{A}}$ \\
\hline
\end{tabular}

All values are mean $\pm \mathrm{SD}$ of three replicates.

${ }^{\text {A-D }}$ Means within a row with different letters are significantly different $(p<0.05)$.

${ }^{1)}$ Control, high-fat emulsion sausage without brown rice fiber; T1, reduced-fat emulsion sausage without brown rice fiber; T2, reducedfat emulsion sausage with $1 \%$ brown rice fiber; T3, reduced-fat emulsion sausage with $2 \%$ brown rice fiber; T4, reduced-fat emulsion sausage with $3 \%$ brown rice fiber; $\mathrm{T} 5$, reduced-fat emulsion sausage with $6 \%$ brown rice fiber

ucts with added dietary fiber have improved textural properties (Choi et al., 2010a; Cofrades et al., 2000; Eim et al., 2008; Lee et al., 2008; Saricoban et al., 2008; Vural et al., 2004). Also, Herrero et al. (2007) reported that a TPA may define the quality of the finished product and provide the best choice of functional ingredients.

Viscosity was significantly affected by the concentration of added brown rice fiber (Fig. 3). The reduced-fat emulsion sausages without brown rice fiber (T1) had the lowest viscosity, whereas increasing the amount of added brown rice fiber significantly increased viscosity $(p<0.05)$. Similar results have been presented for the effect of dietary fiber on the viscosity of meat emulsions (Choi et

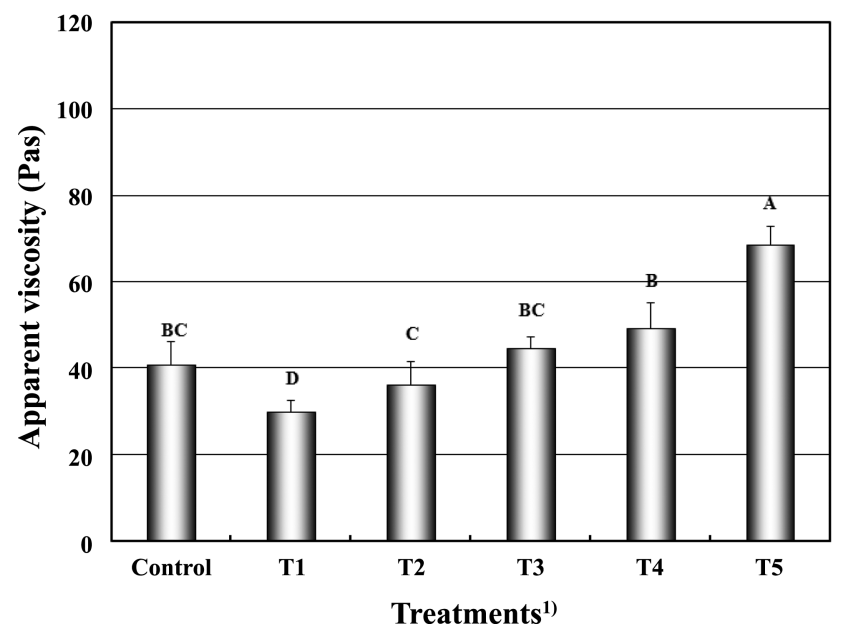

Fig. 3. Apparent viscosity of reduced-fat emulsion meat batters containing various levels of added brown rice fiber. ${ }^{\mathrm{A}-\mathrm{D}}$ Means with different letters are significantly different $(p<0.05) .{ }^{1)}$ Control, high-fat emulsion sausage without brown rice fiber; T1, reduced-fat emulsion sausage without brown rice fiber; T2, reduced-fat emulsion sausage with $1 \%$ brown rice fiber; $\mathrm{T} 3$, reduced-fat emulsion sausage with $2 \%$ brown rice fiber; $\mathrm{T} 4$, reduced-fat emulsion sausage with $3 \%$ brown rice fiber; $\mathrm{T} 5$, reducedfat emulsion sausage with $6 \%$ brown rice fiber al., 2010b; 2011). According to Choi et al. (2008), increasing the viscosity of a meat emulsion is related to added rice bran fiber content. Lee et al. (2008) indicated that dietary fiber provides higher water retention and improved viscosity. Some studies have reported that the viscosity of emulsion batter is important related to emulsion stability (Shand, 2000; Zayas, 1997; Zorba et al., 1993). Aktas and Genccelep (2006) indicated that emulsion sausage batters had a higher correlation with added high-dietary fiber and increased the viscosity of meat batters.

\section{Sensory evaluation}

The sensory traits for reduced-fat emulsion sausages with added brown rice fiber are shown in Table 5. The mean values of color, flavor, tenderness, and juiciness were estimated along with overall acceptability. The color score of the treatments with reduced-fat and added brown rice fiber did not differ significantly compared to that of the control, but the reduced-fat treatment without brown rice fiber (T1) was the lowest $(p<0.05)$. Flavor, tenderness, juiciness, and overall acceptability scores were similar for the control and reduced-fat treatments with 1-3\% of added brown rice fiber. All sensory evaluation scores were lower for the treatment with reduced-fat but without added brown rice fiber (T1) $(p<0.05)$. Some researchers have reported that sensory properties are affected by various added functional ingredients in meat products such as lemon albedo, rice bran fiber, carrageenan, fruit purees, kimchi fiber, and wheat fiber (Choi et al., 2010b; Fernandez-Gines et al., 2004; Lee et al., 2008; Mansour and Khalil, 1997; Turhan et al., 2005). However, Anderson and Berry (2000) reported no differences in observed sensory traits due to a inner pea fiber treatment.

The results indicate that increasing brown rice fiber lev- 
Table 5. Sensory evaluation of reduced-fat sausages containing various levels of added brown rice fiber

\begin{tabular}{lcccccc}
\hline \hline \multirow{2}{*}{ Traits } & \multirow{2}{*}{ Control } & \multicolumn{5}{c}{ Treatments ${ }^{1)}$} \\
\cline { 3 - 7 } & & \multicolumn{1}{c}{$\mathrm{T} 1$} & $\mathrm{~T} 2$ & $\mathrm{~T} 3$ & $\mathrm{~T} 4$ & $\mathrm{~T}$ \\
\hline Color & $8.27 \pm 0.47^{\mathrm{A}}$ & $7.18 \pm 0.87^{\mathrm{B}}$ & $8.18 \pm 0.75^{\mathrm{A}}$ & $8.09 \pm 0.70^{\mathrm{A}}$ & $7.91 \pm 0.70^{\mathrm{A}}$ & $7.73 \pm 1.10^{\mathrm{AB}}$ \\
Flavor & $8.27 \pm 0.79^{\mathrm{A}}$ & $7.45 \pm 0.82^{\mathrm{C}}$ & $8.45 \pm 0.69^{\mathrm{A}}$ & $8.27 \pm 1.01^{\mathrm{AB}}$ & $8.00 \pm 1.00^{\mathrm{BC}}$ & $7.55 \pm 0.93^{\mathrm{BC}}$ \\
Tenderness & $8.73 \pm 1.01^{\mathrm{A}}$ & $7.64 \pm 0.67^{\mathrm{C}}$ & $8.45 \pm 0.82^{\mathrm{AB}}$ & $8.55 \pm 0.93^{\mathrm{AB}}$ & $8.36 \pm 0.92^{\mathrm{BC}}$ & $7.91 \pm 0.70^{\mathrm{C}}$ \\
Juiciness & $8.86 \pm 0.71^{\mathrm{A}}$ & $7.73 \pm 0.90^{\mathrm{B}}$ & $8.27 \pm 0.79^{\mathrm{AB}}$ & $8.36 \pm 0.81^{\mathrm{AB}}$ & $8.59 \pm 0.80^{\mathrm{A}}$ & $8.18 \pm 0.87^{\mathrm{AB}}$ \\
Overall acceptability & $8.82 \pm 0.75^{\mathrm{A}}$ & $7.59 \pm 0.66^{\mathrm{C}}$ & $8.45 \pm 0.69^{\mathrm{AB}}$ & $8.55 \pm 0.82^{\mathrm{AB}}$ & $8.38 \pm 0.67^{\mathrm{AB}}$ & $8.00 \pm 0.63^{\mathrm{BC}}$ \\
\hline
\end{tabular}

All values are mean $\pm \mathrm{SD}$ of three replicates.

${ }^{\text {A-C }}$ Means within a row with different letters are significantly different $(p<0.05)$.

${ }^{1)}$ Control, high-fat emulsion sausage without brown rice fiber; T1, reduced-fat emulsion sausage without brown rice fiber; T2, reducedfat emulsion sausage with $1 \%$ brown rice fiber; T3, reduced-fat emulsion sausage with $2 \%$ brown rice fiber; T4, reduced-fat emulsion sausage with $3 \%$ brown rice fiber; $\mathrm{T} 5$, reduced-fat emulsion sausage with $6 \%$ brown rice fiber

els in reduced-fat emulsion sausage is beneficial for cooking yield, emulsion stability, and viscosity. Hardness, gumminess, and chewiness of reduced-fat emulsion sausages increased as the fiber content increased. The presence of brown rice fiber in a meat product affects its sensory properties. The reduced-fat emulsion sausage with $1-3 \%$ added brown rice fiber can be readily manufactured with high quality and acceptable sensory properties. These results also suggest that using brown rice fiber is a good source of dietary fiber that can be used as a functional ingredient in meat products.

\section{Acknowledgement}

This work was supported by CJ Cheiljedang Corporation. The authors also partially supported by the Brain Korean 21 (BK 21) Project from Ministry of Education and Human Resources Development.

\section{References}

1. Aktas, N. and Genccelep, H. (2006) Effect of starch type and its modifications on physicochemical properties of bolognatype sausage produced with sheep tail fat. Meat Sci. 74, 404408.

2. Anderson, E. T. and Berry, B. W. (2000) Sensory, shear, and cooking properties of lower-fat beef patties made with inner pea fiber. J. Food Sci. 65, 805-810.

3. AOAC (2000) Official methods of analysis of AOAC. 17th ed, Association of Official Analytical Chemists, Washington, DC.

4. Bloukas, I. and Honikel, K. O. (1992) The influence of additives on the oxidation of pork back fat and its effect on water and fat binding in finely comminuted batters. Meat Sci. 32, 31-43.

5. Bourne, M. C. (1978) Texture profile analysis. Food Technol. 32, 62-66.

6. Chin, K. B. and Ban, G. H. (2008) Evaluation of two levels and types of acorn powder on product quality of low-fat sausages as a fat replacer. J. Anim. Sci. Technol. 50, 217-226.

7. Choi, Y. S., Choi, J. H., Han, D. J., Kim, H. Y., Lee, M. A., Jeong, J. Y., Chung, H. J., and Kim, C. J. (2010a) Effects of replacing pork back fat with vegetable oils and rice bran fiber on quality of reduced-fat frankfurters. Meat Sci. 84, 557-563.

8. Choi, Y. S., Choi, J. H., Han, D. J., Kim, H. Y., Lee, M. A., Kim H. W., Jeong, J. Y., and Kim, C. J. (2009) Characteristics of low-fat meat emulsion systems with pork fat replaced by vegetable oils and rice bran fiber. Meat Sci. 82, 266-271.

9. Choi, Y. S., Choi, J. H., Han, D. J., Kim, H. Y., Lee, M. A., Kim, H. W., Lee, J. W., Chung, H. J., and Kim, C. J. (2010b) Optimization of replacing pork back fat with grape seed oil and rice bran fiber for reduced-fat meat emulsion systems. Meat Sci. 84, 212-218.

10. Choi, Y. S., Choi, J. H., Han, D. J., Kim, H. Y., Lee, M. A., Kim, H. W., Jeong, J. Y., and Kim, C. J. (2011) Effects of rice bran fiber on heat-induced gel prepared with pork salt-soluble meat proteins in model system. Meat Sci. 88, 59-66.

11. Choi, Y. S., Choi, J. H., Han, D. J., Kim, H. Y., Lee, M. A., Lee, E. S., Jeong, J. Y., Paik, H. D., and Kim, C. J. (2008) Effects of rice bran fiber on quality of low-fat Tteckgalbi. Food Sci. Biotechnol. 17, 959-964.

12. Choi, Y. S., Lee, M. A., Jeong, J. Y., Choi, J. H., Han, D. J., Kim, H. Y., Lee, E. S., and Kim, C. J. (2007) Effects of wheat fiber on the quality of meat batter. Korean J. Food Sci. Ani. Resour. 27, 22-28.

13. Cofrades, S., Guerra, M. A., Carballo, J., Fernandes-Martin, F., and Colmenero, F. J. (2000) Plasma protein and soy fiber content. Effect on bologna sausage properties as influenced by fat level. J. Food Sci. 65, 281-287.

14. Cofrades, S., Lopez-Lopez, I., Solas, M. T., Bravo, L., and Jimenez-Colmenero, F. (2008) Influence of different types and proportions of added edible seaweeds on characteristics of low-salt gel/emulsion meat systems. Meat Sci. 79, 767776.

15. Eim, V. S., Simal, S., Rosselló, C., and Femenia, A. (2008) Effects of addition of carrot dietary fibre on the ripening process of a dry fermented sausage (sobrassada). Meat Sci, 80, 173-182.

16. Fernández-Ginés, J. M., Fernandez-López, J., Sayas-Bar- 
berá, E., Sendra, E., and Pérez-Álvarez, J. A. (2004) Lemon albedo as a new source of dietary fiber: Application to bologna sausages. Meat Sci. 67, 7-13.

17. Fernández-López, J., Sendra, E., Sayas-Barberá, E., Navarro, C., and Pérez-Alvarez, J. A. (2008) Physico-chemical and microbiological profiles of "salchichón" (Spanish dry-fermented sausage) enriched with orange fiber. Meat Sci. 80, 410-417.

18. García, M. L., Dominguez, R., Galvez, M. D., Casas, C., and Selgas, M. D. (2002) Utilization of cereal and fruit fibers in low fat dry fermented sausages. Meat Sci. 60, 227-236.

19. Herrero, A. M., Ordonez, J. A., Romero de Avila, Herranz, B., de la Hoz, L, and Cambero, M. I. (2007) Breaking strength of dry fermented sausages and their correlation with texture profile analysis (TPA) and physic-chemical characteristics. Meat Sci. 77, 331-338.

20. Huang, S. C., Shiau, C. Y., Liu, T. E., Chu, C. L., and Hwang, D. F. (2005) Effects of rice bran on sensory and physicchemical properties of emulsified pork meatballs. Meat Sci. 70, 613-619.

21. Hughes, E., Cofrades, S., and Troy, D. J. (1997) Effects of fat level, oat fiber and carrageenan on frankfurters formulated with 5, 12 and 30\% fat. Meat Sci. 45, 273-281.

22. Hughes, E., Mullen, A. M., and Troy, D. J. (1998) Effects of fat level, tapioca starch and whey protein in frankfurters formulated with $5 \%$ and $12 \%$ fat. Meat Sci. 48, 169-180.

23. Jiménez-Colmenero, F. (1996) Technologies for developing low-fat meat products. Trends Food Sci. Technol. 7, 41-48.

24. Lee, M. A., Han, D. J., Jeong, J. Y., Choi, J. H., Choi, Y. S., Kim, H. Y., Paik, H. D., and Kim, C. J. (2008) Effect of kimchi powder level and drying methods on quality characteristics of breakfast sausage. Meat Sci. 80, 708-714.

25. Luruena-Martinez, M. A., Vivar-Quintana, A. M., and Revilla, I. (2004) Effect of locust bean/xanthan gum addition and replacement of pork fat with olive oil on the quality characteristics of low-fat frankfurters. Meat Sci. 68, 383-389.

26. Mansour, E. H. and Khalil, A. H. (1997) Characteristics of low-fat beefburger as influenced by various types of wheat fibers. Food Res. Int. 30, 199-205.

27. Park, H. J., Han, S. W., Lee, D. Y., Kim, H. K., Jeong, H. C., Park, H. H., and Song, S. H. (2009) A method for preparing protein concentrate from rice bran. International Publication Number WO 2009/035186 A1.
28. Piñero, M. P., Parra, K., Huerta-Leidenz, N., Arenas de Moreno, L., Ferrer, M., Araujo, S., and Barboza, Y. (2008) Effect of oat's soluble fibre ( $\beta$-glucan) as a fat replacer on physical, chemical, microbiological and sensory properties of low-fat beef patties. Meat Sci. 80, 675-680.

29. Sánchez-Zapata, E., Muñoz, C. M., Fuentes, E., FernándezLópez, J., Sendra, E., Sayas, E., Navarro, C., and PérezAlvarez, J.A. (2010) Effect of tiger nut fibre on quality characteristics of pork burger. Meat Sci. 85, 70-76.

30. Saricoban, C., Ozalp, B., Yilmaz, M. T., Ozen, G., Karakaya, M., and Akbulut, M. (2008) Characteristics of meat emulsion systems as influenced by different levels of lemon albedo. Meat Sci. 80, 599-606.

31. SAS. (2008) SAS/STAT Software. Release 9.2, SAS Institute Inc., Cary, NC, USA.

32. Shand, P. J. (2000) Textural, water holding, and sensory properties of low-fat pork bologna with normail and waxy starch hull-less barley. J. Food Sci. 65, 101-107.

33. Turhan, S., Sagir, I., and Ustun, N. S. (2005) Utilization of hazelnut pellicle in low-fat beef burgers. Meat Sci. 71, 312316.

34. Vural, H., Javidipour, I., and Ozbas, O. O. (2004) Effects of interesterified vegetable oils and sugarbeet fiber on the quality of frankfurters. Meat Sci. 67, 65-72.

35. Wong, K. H. and Cheung, P. C. K. (2000) Nutritional evaluation of some subtropical red and green seaweeds: Part 1 proximate composition, amino acid profiles and some physicochemical properties. Food Chem. 71, 475-482.

36. Yilmaz, I. (2005) Physicochemical and sensory characteristics of low fat meatballs with added wheat bran. J. Food Eng. 69, 369-373.

37. Yilmaz, I. and Dağ lioğlu, O. (2003) The effect of replacing fat with oat bran on fatty acid composition and physicochemical properties of meatballs. Meat Sci. 65, 819-823.

38. Zayas, J. F. (1997) Solubility of protein. In: Zayas, J. F. (ed) Functionality of proteins in food. Springer-Verlag Berlin Heigedlbeg, Berlin, Germany, pp. 6-75.

39. Zorba, O., Gokalp, H. Y., Yetim, H., and Ockerman, H. W. (1993) Salt, phophate and oil temperature effects on emulsion capacity of fresh or frozen meat and sheep tail fat. $J$. Food Sci. 58, 492-496.

(Received 2011.5.27/Revised 2011.7.21/Accepted 2011.7.26) 